\title{
Case Study of Problem-Based Teaching Material Development Simulation in School
}

\author{
Memet Sudaryanto ${ }^{1}$, Muhammad Rohmadi², Chafit Ulya ${ }^{3}$, Keken Wulansari ${ }^{4}$, Ulfa Rizqi \\ Putri ${ }^{5}$ \\ \{memetsudaryanto@gmail.com ${ }^{1}$,mamad_r76@staff.uns.ac.id ${ }^{2}$, chafit@staff.uns.ac.id ${ }^{3}$ \\ kekenw@student.uns.ac.id ${ }^{\overline{4}}$, ulfakiky@student.uns.ac.id ${ }^{5}$ \} \\ Universitas Jenderal Soedirman, Indonesia ${ }^{1}$ \\ Universitas Sebelas Maret, Indonesia ${ }^{2345}$
}

\begin{abstract}
Teaching materials that support future needs in the learning process require students to understand scientific concepts more contextually. Synergy is needed from the less-than-optimal learning system, teacher competence, student motivation, facilities and infrastructure, and the learning atmosphere which is built. It is essential to describe the need for teaching materials that are able to build problem-based learning concepts to see the readiness of teachers in providing representative teaching materials. The research method is a case study by collaborating qualitative and quantitative research in order to measure the absorption of information in the classroom. This study used a sample of teachers and prospective teachers in the fields of science, humanities, and social affairs. The results showed that case study as a learning approach and teaching material development was able to increase student sensitivity in responding to learning conflicts that occurred in the classroom. Furthermore, students are also trained in critical and analytical thinking skills to find solutions to learning problems found through the development of problem-based teaching materials. The sensitivity of prospective teachers is needed to optimize the four skills of teachers, especially pedagogy, which is the ability of prospective teachers to manage a learning process or teaching and learning interactions with students.
\end{abstract}

Keywords: Pedagogy, Case Study, Learning Conflict

\section{Introduction}

The teacher's ability to determine the direction of learning depends on the sensitivity and experience during teaching. Teachers need to know and understand the situation of students with regard to academic and extracurricular potential. Teachers are expected to be able to prepare each learning component and organize learning according to the demands of society's needs in the future. Furthermore, the changing needs demand paradigm shift both conceptually and in practice. In a learning environment, students will be encountered with how they can develop and learn. Not only that, student teacher candidates will also be able to develop and teach their students in school.

This need is supported by good classroom management skills. Moreover, learning needs are also enhanced by various activities both inside and outside the classroom. The ability of teachers (as well as prospective teachers) to control these factors is a demand for teacher professionalism. 
Furthermore, creating a conducive learning environment and according to the characteristics of each student is also an important thing for teachers to master. Pedagogical competencies which must be mastered by prospective teachers emphasize the management of learning materials, which is discussing the learning experiences that will be obtained. Good learning material needs to be supported by good classroom management, determining the approach and learning model that is most appropriate to the student's learning method [1] [2]. The more learning developments that lead to problem-based learning, the more alternatives students will get that are correlated with the material provided by the teacher [3].

Students at each school level have unique and different characteristics. Schools have taken advantage of the average age of students by starting to teach them independently. The independent learning process requires teachers to map the needs of students who are used as learning resources in the classroom. Learning resources are very representative of the needs of students [4]. Not only learning resources, fulfilling educational needs can be seen from several main educational problems that come from the point of view of educational planning. These problems include: quality of education, management of teaching and learning processes at the macro level, supervision in efforts to improve the quality of learning, supervision in efforts to improve the quality of education at the micro level, and educational institutions.

The success of learning objectives is influenced by several factors, including mapping the needs and abilities of students, allocating appropriate time, changing attitudes and behavior of students, varied learning resources, adequate facilities and infrastructure, support from various parties, and the ability of teachers [5]. The characteristics of students need to be studied in depth in order to determine learning methods and achieve optimal learning outcomes. This information is needed by teachers and learning researchers as well as learning scientists as: (1) the basis for the development of learning theories in accordance with the conditions of students and their socio-culture; (2) foundation in conducting research and development of learning programs; and (3) the basis for the designer to produce learning materials, such as text books and other media and learning resources. These various categories are able to construct a textbook so that students can easily learn in the situations and conditions they want according to the learning resources needed.

Learning is not only a process in the classroom, but the independent learning process also needs to be improved. The ideal independent learning process certainly requires a supportive and structured reference. Textbooks need to provide structured content for the learning needs of students. Learning events should ideally occur in interaction and communication activities between teachers who teach and all students in the classroom. In these activities, materials are used for students to learn, which are sensed, thought, felt, imagined, and performed [6]. Textbooks provide material that has been prepared, selected, and the scope and sequence is determined so as to make learning easier for students.

Textbooks are seen as a means of communicating knowledge. Textbooks used in schools by teachers or students must clearly be able to communicate information, concepts, knowledge, and develop abilities in such a way that they can be understood by both students and teachers. In other words, textbooks are a medium for presenting a subject in an orderly manner for teaching and learning purposes so that they are useful for the construction of a specific learning situation [7]. Learning that is oriented towards future needs can provide a stimulus for students to gain new experiences in relation to their environment and be able to identify the values they want to know in depth through textbooks [8]. Furthermore, the second stage is to design a program of teaching activities that use the environment as a learning resource in accordance with the objectives of learning outcomes and the selected 
topic. The teacher organizes students in groups or individually, records and administers as the first stage.

\section{Research Method}

This research is a case study of the development of problem-based teaching materials in schools as seen from both qualitative and quantitative approaches. Qualitatively, this study examines the phenomenon of textbook development conducted by teachers in both humanities, science, and social classes. This study used interactive analysis techniques by collecting data in the form of selecting teaching materials, developing teaching materials, and reducing teaching materials according to the characteristics of students, teachers, and schools. Quantitatively, this study conducted a survey to support qualitative data, which is collecting information in the form of material distribution and interest in developing teaching materials performed by teachers [9]. Material distribution data were compared between the needs of teachers and prospective teachers in order to explain pedagogy sensitivity to prospective teachers in Indonesia.

The validity of the collected data is checked. Trying to make the data validity obtained was completed by triangulation [10]. This research used method triangulation and source triangulation. Triangulation method is checking the correctness of data from several different sources using several methods. The triangulation conducted in this study were interviews and observations. To test the validity of the data in this study, researchers used theory of triangulation techniques, informant review methods and techniques.

\section{Results and Discussion}

In general, the description of the material had been completed on the table of contents and concept maps. The material described was described clearly and clearly. It can be seen from the three activities that are consistently conducted in one chapter with another. It appears, in this lesson text book has divided three activities that must be done by students. After establishing the context, the first activity is modeling. Various forms and types of discourse models are presented to deliver the second material or activity. The first activity is modeling. In this activity, students will be encountered with several discourses that become models and introduce material to be discussed next.

Indonesian textbooks refer to many activities to build context in learners. The second activity is a group activity. Of course, group activities will be easier than students to write directly the tasks they will face. Thus, in the second activity material, students will be asked to make assignments in groups so that they can discuss with other friends. When students have difficulty completing their assignments, each of them can discuss with each other to solve problems and overcome them. Hence, the training performed by students to solve the problem can be solved properly. On the other hand, before the teacher takes action to solve student problems, students are able to solve the problem and form a character of tolerance.

The third activity is an independent activity. This activity trains the independence of students. Furthermore, it also provides time for students to develop their own ideas. This activity is a parameter of the success of students in completing their tasks and getting scores individually without involving other students [11]. If viewed from the progress of the 
students' scientific development, it can be seen from the three activities conducted, the presentation of the material has been done well, which is from easy to difficult. Moreover, modeling patterns are the most concrete way to teach students. Thus, the material to be delivered can be clearly illustrated by students without having to grope about the material to be studied by students.

The material has been presented systematically. It can be seen in the division of tasks between activities. Each activity has been well organized. Nothing consistency of the material presented too much, nor too little. Some of the material presented in this Indonesian language textbook is the same. The material given for the first time was to look at the given model (modeling) in this activity, the task of students was to check and study each given model text. After reviewing, the students will be asked to examine the features of the text, so that the text can be an example or model for the text that students will make in the second activity. The study will lead to the understanding of students who will be identified by the tests conducted. After that, they will also be asked to recognize the structure of the text and understand the elements that compose it.

In the second activity, students will be asked to compile the text with sentences that they have made themselves and have an understandable order and logic. After students are proven to be able to complete the text they make in groups, the students' tasks in the second activity have been well intertwined [12]. To discover the understanding of individual students, it was tested in the third activity. This activity looks at the ability of students in compiling text and identifying text shortcomings. It is also due to the conformity with KI (Core Competency) and $\mathrm{KD}$ (Basic Competency) which have been used as guidelines in the development of these textbooks. In the end, students must also be able to revise the results of their work and arrange them back better.

Suitability with the curriculum is the main basis for textbooks. Furthermore, this suitability must also be seen from the developing theoretical concepts of the material presented. Anggela, et al. (2013) explained that the main content of the textbook is the structure of the textbook and conformity to the curriculum, next is the concept map and competencies to be achieved. The concept map will make it easier for users to use textbooks with these character values, while the competencies to be achieved contain competency standards, basic competencies, as well as indicators of achievement of learning outcomes that students must master. Textbook material consists of concepts in certain fields of science which are arranged systematically so that they become theories that shape knowledge to obtain the desired competencies. All material has been discussed in accordance with the core competencies and basic competencies presented in the curriculum guide. In writing textbooks, there are some materials that are not summarized in the textbook so that according to the assessment guidelines, they cannot get a perfect assessment.

Textbooks should be able to present teaching materials in good and correct language. Here, it can be seen whether the use of language is reasonable, interesting, and in accordance with the development of students or not. One of the slick presentations is the diverse pattern of paragraph development so that the textbooks are not boring. This research shows that most paragraphs have been developed with a variety of patterns, including deductive-inductive, analogy, based on chronology (reasoning), comparison/contradiction, examples, causation, broad definitions, and classifications. The decomposition of the material was presented systematically and consistently, which was from concrete to abstract material, and easy material to difficult material. This statement is judged from the use of a concept map which shows three main activities, consisting of modeling, group assignments, and ending with 
independent assignments. Illustrations serve to clarify concepts/theories and can be made in the form of images, tables, graphs, diagrams, sketches, plans, maps, or portraits.

Using descriptive illustrations can be made shorter, clearer, focused, and interesting. However, the assignment was deemed incomplete, the instructions for handling the questions were less easy to understand. On the other hand, the length between the chapters is proportional and supported by cohesiveness. This proportion and cohesiveness are supported by the opinion of Haslinda which asserted that books should have unity or cohesiveness in helping participants think in the learning process in class to achieve the curriculum that is being applied [13]. Hence, from the various findings and links to the theory, it can be seen that the illustration of textbooks is still insufficient to use, because in addition to their use as theory support, it is also to make students more interested in the book.

Readability test conducted in this study used the 7th word punching. This is based on a limited test that was found by calculating the gap test on the same text as the 7th and 10th word punching [14]. From this calculation, there was no significant difference between the 7 th word and the 10th word. This study shows that 3 texts were used, 2 of which have a high readability level, while one text has a moderate readability level.

The involvement of case study research on the development of teaching material in learning, among others, is that the teacher gets a reference used to fix textbooks while teaching, so that errors in the textbook can be fun material to discuss. Students as readers certainly gain experience in using good and correct language through this study [15]. Hence, learning activities will be more structured and systematic to achieve learning based on the ability to think critically, analytically, creatively, and solve problems in a solution. Teachers have many opportunities and times in selecting appropriate teaching materials for their students. Teachers do not have to be tied to just one textbook as learning material in the classroom. Teachers can collect resource books that can be used in classroom teaching.

\section{Conclusions}

Teaching materials developed by teachers and prospective teachers in this study are relatively not significantly different. The teaching materials have been well organized, although some of the criteria have not been achieved optimally. While almost all of the core competencies and basic competencies have been summarized, as well as the routine activities of students to practice language skills. Teaching materials were arranged systematically, including components described very neatly. Furthermore, the material presented was very consistent, divided into learning activities. Learning activities consist of concept building activities, followed by group activities ending with independent activities. The development of such learning patterns is repeated from the first chapter to the end. Even though some chapters are disproportionately long, the inter-chapters are well integrated, including complete systematics.

Unfortunately, much of the material presented is too convoluted. Based on the further analysis conducted, it was found that the interest of teachers and prospective teachers in developing problem-based teaching materials increased. It is expected to be able to help students to be trained in critical and analytical thinking skills in order to find solutions to learning problems found through the development of problem-based teaching materials. Before asking students to read the prepared reading material, the teacher must determine the level of readability of the material. 


\section{References}

[1] J. Pearce, R. A. Mulder, and C. Baik, "Involving Students in Peer Review: Case Studies and Practical Strategies for University Teaching," Cent. Study High. Educ., 2009.

[2] K. Saddhono, A. Amalia, I. K. Sudarsana, and A. Indahingwati, "Multimedia Use for Beginner Level of Teaching Languages for Deaf Children: Study in Special Schools in Surakarta," J. Phys. Conf. Ser., vol. 1363, no. 1, 2019.

[3] R. Barnard, J. C. Richards, and T. S. Rodgers, "Approaches and Methods in Language Teaching," TESOL Q., 2002.

[4] G. Attwell, "Personal Learning Environments - the future of eLearning ?," Lifelong Learn., 2007.

[5] J. Hattie and H. Timperley, "The power of feedback," Review of Educational Research. 2007.

[6] R. J. Fogarty and B. M. Pete, "How to differentiate learning: Curriculum, instruction, assessment.," How to differentiate learning: Curriculum, instruction, assessment. 2005.

[7] R. Winarni, S. Y. Slamet, and K. Saddhono, "Development of Indonesian literature textbook with character education through information and communication technology (ICT) learning based,” Int. J. Eng. Technol., 2018.

[8] L. Greenstein, "Assessing 21st century skills: A guide to evaluating mastery and authentic learning,” Assess. 21 st century Ski. A Guid. to Eval. mastery authentic Learn., 2012.

[9] Markhamah, A. Ngalim, M. Muinudinillah Basri, and A. Sabardila, "Comparison of Personal Pronoun between Arabic and Its Indonesian Translation of Koran,” Int. J. Appl. Linguist. English Lit., 2017.

[10] M. B. Miles and M. A. Huberman, Analisis Data Kualitatif: Buku Sumber Tentang MetodeMetode Baru. 2012.

[11] M. Rohmadi, C. Ulya, M. Sudaryanto, and M. Ximenes, "Feasibility Analysis of Basic Writing and Reading Materials for Foreign Speakers," 2020.

[12] A. Gottlieb, "Anthropological Writing," in International Encyclopedia of the Social \& Behavioral Sciences: Second Edition, 2015.

[13] H. Haslinda et al., "Evaluation of e-Book applications using ISO 25010," in 2nd International Symposium on Technology Management and Emerging Technologies, ISTMET 2015 Proceeding, 2015.

[14] T. Loughran and B. Mcdonald, "Measuring readability in financial disclosures," J. Finance, 2014

[15] L. Zhang, "Reading and Writing Connections," in The TESOL Encyclopedia of English Language Teaching, 2018 